$11-1988$

\title{
Swinburne's Speech to the Royal Literary Fund, May 2, 1866
}

Terry L. Meyers

William \& Mary, tlmeye@wm.edu

Follow this and additional works at: https://scholarworks.wm.edu/aspubs

Part of the Literature in English, British Isles Commons

\section{Recommended Citation}

Meyers, Terry L., Swinburne's Speech to the Royal Literary Fund, May 2, 1866 (1988). Modern Philology, 86(2), 195-201.

https://doi.org/10.1086/391693

This Article is brought to you for free and open access by the Arts and Sciences at W\&M ScholarWorks. It has been accepted for inclusion in Arts \& Sciences Articles by an authorized administrator of W\&M ScholarWorks. For more information, please contact scholarworks@wm.edu. 
Swinburne's Speech to the Royal Literary Fund, May 2, 1866

Author(s): Terry L. Meyers

Source: Modern Philology, Vol. 86, No. 2 (Nov., 1988), pp. 195-201

Published by: The University of Chicago Press

Stable URL: https://www.jstor.org/stable/438546

Accessed: 14-11-2018 15:26 UTC

JSTOR is a not-for-profit service that helps scholars, researchers, and students discover, use, and build upon a wide range of content in a trusted digital archive. We use information technology and tools to increase productivity and facilitate new forms of scholarship. For more information about JSTOR, please contact support@jstor.org.

Your use of the JSTOR archive indicates your acceptance of the Terms \& Conditions of Use, available at https://about.jstor.org/terms

The University of Chicago Press is collaborating with JSTOR to digitize, preserve and extend access to Modern Philology 
nize that the poet's brimleade involves much more than getting rewarded for crossing the sea, we too are obliged to "drink deep" and, as far as our lines will reach, at least to try to sound the depths of meaning which lie below the literal surface of the poet's words. The literal translation of 1051-54a might be recast along the lines of:

More deeply yet, did the lord of earls for each Of those who with Beowulf plumbed the sea-paths, There on the bench pulling at mead, fill their sails With flowing wealth, ply them with golden legacy, And then arrange for that one man to be Paid for with solid gold, whom Grendel earlier Had wickedly killed, ...

$[1050-54 a]$

University of Denver

\section{Swinburne's Speech to the Royal Literary Fund, May 2, 1866}

\section{Terry L. Meyers}

Algernon Charles Swinburne made so few formal presentations to any kind of audience that only a single public one, so far as I know, is recorded-his reply to a toast at the Royal Literary Fund Dinner of May 2, 1866.' Scholars have thought they had no access to the speech, for, although Edmund Gosse prints a part of it in his biography of Swinburne (along with a slightly distorted account of its presentation) and other biographers include other bits and pieces, it has, to all intents and purposes, dropped from sight; only those able to see the papers of the Royal Literary Fund, Gosse implies, might glimpse the text of what Swinburne said. Surprisingly, however, the full text is available, as is enough other information that one can reconstruct the poet's presentation more completely than heretofore and see the speech as a rather more complex document than has been assumed.

In his Life of Algernon Charles Swinburne, Edmund Gosse introduces Swinburne's speech as part of the anticipation of Poems and Ballads orchestrated by Lord Houghton-indeed, Gosse implies, perhaps the buildup even encouraged the excessive reaction that has entered literary history. Gosse recounts the evening at the Royal Literary Fund with great skill, intimating Houghton's having pressured a somewhat reluctant committee to invite the young poet to be honored; ${ }^{2}$ sketching

1/Swinburne did of course give many readings to groups of his friends and had been as an undergraduate an active member of Old Mortality (see Gerald C. Monson, "Old Mortality at Oxford," Studies in Philology 67 [1970]: 359-89).

2/Lord Houghton's biographer, James Pope-Hennessy, makes no mention of Houghton's efforts in this particular regard in his admirable account of the relations between Swinburne and his mentor (see Monckton Milnes: The Flight of Youth. 185I-1885 [New York, 1955]).

() 1988 by The University of Chicago. All rights reserved. 0026-8232/89/8602-0005\$01.00 
the distinguished audience to be addressed (among others, Dean Stanley, Henry Reeve, Anthony Trollope, Sir Samuel Baker, Leslie Stephen, Frederick Leighton, Lord Milton, and the like); and recalling the toast itself by George Stovin Venables to "The Historical and Imaginative Literature of England" and the introductions of the speakers to reply to the toast, including Charles Kingsley, who endorsed Venables's praise of Swinburne as "the representative of the future in English poetry." ${ }^{3}$

Gosse himself, of course, was not present, and though he undoubtedly had good sources for his representation of the evening, he was wrong in at least one respect. Probably depending on his knowledge of Swinburne's usual reading voice and apparently nervous behavior, Gosse writes that Swinburne "recited, in shrill, monotonous tones, the short essay which he had learned by heart." ${ }^{4}$ In fact, there is contemporary evidence that paints a different picture. Moreover, the account, which is in an unidentified newspaper clipping among the Houghton Papers at Trinity College, Cambridge, may well have helped to form, or confirm, the image of Swinburne in Henry Adams's mind which he recalled when he came some years later to depict the man he thought "a real genius." The "English author" who provides the newspaper account writes with great admiration of Swinburne's presence:

After Mr. Kingsley arose Mr. Swinburne. He spoke in such a low voice that I could only see his lips move, and hear no word. But it was enough to see Swinburne's face-especially with his cheek and eye kindled and I shall never forget it. A small, young, even boyish man, with handsome, regular features and smooth skin; with eyes that glitter; with thin, flexible lips, whose coldness is in strange contrast to the passionate intensity of his eyes; with a great deal of reddish hair that surrounds his face like a halo. He seemed to me like some wild bird of rare and beautiful plumage, which has alighted in our uncongenial climate, and who is likely to die before it is acclimatised. No one who has ever looked upon his face would doubt for a moment that he is a man of genius.

Who this otherwise unidentified English author is, of course, cannot now be recovered with any certainty, but it is intriguing to think that Henry Adams might have read the vivid description and that it might have revived in his mind when he came to compose his own recollection of Swinburne as he was when he first met him at Fryston, Houghton's country house, in December 1862: "The fourth [guest] was a boy, or had the look of one, though in fact a year older than Adams himself. $\mathrm{He}$ resembled in action-and in this trait, was remotely followed, a generation later, by another famous young man, Robert Louis Stevenson-a tropical bird, high-crested, long-beaked, quick-moving, with rapid utterance and screams of humour, quite unlike any English lark or nightingale. One could hardly call him a crimson macaw among owls, and yet no ordinary contrast availed." 6

3/For Gosse's descriptions, see Edmund Gosse, Life of Algernon Charles Swinburne, in The Complete Works of Algernon Charles Swinburne, ed. Thomas James Wise and Edmund Gosse, 20 vols. (London, 1925-27), 19:136 38; hereafter the Works will be cited as the Bonchurch edition. Samuel Chew prints part of Charles Kingsley"s "sly remarks" on Swinburne (Swinburne [Boston, 1929], pp. 68-69).

4/Bonchurch ed., 19:136. Gosse goes on to characterize the presentation of the speech when he alludes to Swinburne's "feverish outpourings of genius" (pp. 137-38).

5/ Henry Adams, The Education of Henry Adams (New York, 1946), p. 141.

6/lbid., p. 139. 
Four years after this first meeting, Adams was at the dinner of the Royal Literary Fund when Swinburne spoke, for he notes in a letter the day the dinner was to be held that he was going to go, "to swell the noble Houghton's train." And he recalled in The Education of Henry Adams that the last time he saw Swinburne was that evening, when "Monckton Milnes summoned his whole array of Frystonians to support him in presiding at the dinner of the Authors' Fund, when Adams found himself seated next to Swinburne, famous then, but no nearer [in friendship than the two had been at their first meeting]. They never met again." 8

The text of Swinburne's remarks is available in a work that has escaped the notice of Swinburne scholars. ${ }^{9}$ In David Williams: Founder of the Royal Literary Fund, ${ }^{10}$ E. V. Lucas quotes the whole of Swinburne's reply to the toast "To the Historical and Imaginative Literature of England":

My Lord and Gentlemen, there is one thing which lightens my sense of embarrassment and inadequacy on being desired to respond to this toast - the hope that the speech of my predecessor will atone for mine; as, under any circumstances, I am conscious that the former must efface the latter, and glad to shelter my failure under his success. As to the question of literature, it has been, as far as I can see or judge, already exhausted on all sides but one. In the imaginative literature of the present day, I at least can discern no more promising sign than the constant and tenacious influence of England upon France, of France upon England. This mutual and reciprocal influence, valuable as it is and fruitful as it must be, is partially, but is not wholly, a new thing. The middle ages brought forth a trinity of great poets: Dante, the Italian noble; Chaucer, the English gentleman; Villon, the French plebeian (hear, hear). We have to do at present with the Englishman only. Chaucer touches Dante with reluctance, almost with repulsion, uses him for a little, then recoils, and drops him as a child might drop a hot iron. 'I cannot go on; if you want more, apply to Dante." 11 So much for the Italian influence; and yet France had then no poet comparable, even from afar off, to Dante. But when Chaucer comes upon the poetry of France he feels instantly at home. The spirit of southern France brightens and warms his verse; the hot sweet breath of Provence satiates and excites him. He translates even (in part) the intolerable Roman de la Rose, but the real tribute to France is not there; it must be sought in his Court of Love, impregnated with Provençal fancy, permeated with Albigensian faith $;{ }^{12}$ in his Troilus and Creseide, filled from end to end with that fierce monotony of tenderness, that bitter absorption of life, which has made the heathenish love of Provençal fighters and singers a proverb to this day.

7/ The Letters of Henry Adams, ed. J. C. Levenson et al. (Cambridge, Mass., 1982), 1: 505.

8/Adams, Education, pp. 143-44. Pope-Hennessy points out one further meeting Adams does not refer to, in July, 1864 (see Pope-Hennessy, p. 141).

9/Gosse prints a portion of the first paragraph of the text in his Life (p. 148); a later part of the text appears most recently in Philip Henderson's Swinburne: The Portrait of a Poet (London, 1974), where Henderson follows Georges Lafourcade's truncated text, with the responses of the audience interpolated (see La Jeunesse de Swinburne, 2 vols. [Paris, 1928], 1:238).

10/E. V. Lucas, David Williams: Founder of the Royal Literary Fund (London, 1920), pp. 43-47. Lucas includes Venables's full introductory remarks as well, with his evocation of the leading poets of the age: Tennyson, Browning, Henry Taylor, William Barnes, Coventry Patmore, and Lord Houghton. Noting their age ("their time is not passed, but is passing away"), Venables sees Swinburne as the next generation to whom the lamp is to be passed. I have compared Lucas's text with that printed in the "Report of the Anniversary, 1866" and corrected it accordingly. I am grateful for a photocopy of the otherwise unattainable report generously supplied by the Royal Literary Fund.

11/Swinburne probably has in mind here The Monk's Tale (lines 2459-62). Mario Praz eludicates the influence of Dante on Chaucer in terms not far removed from Swinburne's seemingly idiosyncratic view (see "Chaucer and the Great Italian Writers of the Trecento," in The Flaming Heart [Gloucester, Mass., 1966], esp. pp. 47-56). Piero Biotani explores the "mysterious, puzzling and elusive" (p. 116) relationship of Chaucer to Dante in "What Dante Meant to Chaucer" in his book of essays Chaucer and the Italian Trecento (Cambridge, 1983).

12/ Neither the Roman de la Rose nor the Court of Love is today received as canonical. 
This influence, it may be said, was provincial and temporary; yet it had its day, and did its work. But now the action is mutual, it is not on one side only; it enforces a reaction. Take the last few years only, and you will see the son of the greatest French poet attempt and accomplish the best translation possible of the greatest English poet (hear, hear); you will see the father of that son dedicate to the memory of Shakespeare, inscribe to the people of England, such a book as no Englishman could have written since the death of Shakespeare himself (cheers). Some may feel ashamed, some will feel proud, that the supreme tribute to the greatest of English poets should have remained unwritten till the advent of the first among later poets worthy to stand near him. He who has best praised Shakespeare, is hitherto the sole successor of Shakespeare-Victor Hugo ${ }^{13}$ This is one point of contact, and one worth notice; another is this: that M. Charles Baudelaire, one of the most exquisite, most delicate, most perfect poets of the century - perfect in sound, in colour, in taste of metre and in tone of emotion-has devoted half his time to the translation and introduction of English writers among the French - not without fruit, and not without cost. In England I will take but one instance: French influence is no less visible than Grecian instinct in one of the most admirable among poets, one of the most brilliant and subtle among essayists now alive; whose claim to either crown is not less recognised in France than in England. For the higher literature of either nation I can imagine no fairer augury than such omens as these afford (cheers).

Swinburne's speech is interesting not just for its being his only formal and public utterance, but also for its tonal ambiguity. At first glance the speech seems to offer no difficulty - it is a decorous, dignified, and graceful performance, suiting the audience and the occasion, fulfilling Swinburne's promise of cool aplomb in announcing his topic to Lord Houghton the month before: "I got a note yesterday about the dinner and will say my say as I can. Of course I shall blow a small trumpet before Hugo. I thought something might be said of the new mutual influence of contemporary French and English literature-e.g., the French studies of Arnold and the English of Baudelaire." ${ }^{14}$ Moreover, the speech allows Swinburne to identify his own poetic allegiances in his implicit identification with Chaucer and, of course, Baudelaire and to compliment his country and his countrymen even as it allows him to turn, in the conclusion, with a deft compliment, to Matthew Arnold. It is hardly surprising that those biographers and critics who have read the speech in fragments treat it with little caution.

If someone were to object that this well-mannered and decorous Swinburne seems not to match the Swinburne we know so well in the 1860 s, the Swinburne whose reputation for public and private eccentricity was beginning to be noted with nervousness, there is a response available. Besides the fervent protestations and remonstrations in reply to the concerns of such friends as Pauline, Lady Trevelyan and William Michael Rossetti about his behavior, we have to remember that Swinburne always was concerned to be a gentleman. William Bell Scott's insight is particularly acute when he suggests to Pauline, Lady Trevelyan in November 1865 how best to raise problems of drinking and behavior with Swinburne: "With all his boasting of himself and all his belongings he is very sensitive about society." 15 Moreover, Arthur J. Munby, an acquaintance who saw both Houghton and Swinburne within a short time of the speech, records, skeptically, Houghton's sense of

13/The references are, of course, to Victor Hugo and to his son, and to their works: Hugo's William Shakespeare (1864), dedicated to England, and François-Victor Hugo's eighteen-volume translation of Shakespeare's CEuvres Completes.

14/The Swinburne Letters, ed. Cecil Y. Lang, 6 vols. (New Haven, Conn., 1959-62), 1:162-63 (hereafter cited as Letters).

15/Ibid., 1:136. 
nurturing Swinburne ("said he has been S's only friend") just before the event (March 17, 1866) and Swinburne's apparent moderation not long after it: "Tuesday, 8 May [1866] . . . coffee upstairs, when Swinburne joined us. . . with all his flightly restless manner, he talked without his old pretentiousness \& paradox, \& showed simply such pure enthusiasm as a poet ought to have: which pleased me, after all one has heard of his 'bumptiousness' of late."16

And yet, as decorous as the speech appears to be, it remains troubling. We can, of course, overlook the somewhat unusual understanding of Chaucer's relation to Dante. But it is much harder to overlook Swinburne's exaggeration of Baudelaire's involvement with English literature. ${ }^{17}$ Edgar Allan Poe writes in English, but he is not English, and Swinburne never thought he was. Even more startlingly, what are we to make of a man who praises Arnold both for his "Grecian instinct" and for his knowledge of French literature when we know how little Swinburne thought of both? For all his admiration of Greek qualities in Arnold's poetry, Swinburne had, after all, been provoked, in part, to write Atalanta in Calydon by the very lifelessness of Arnold's attempt to realize the form of Greek tragedy in Merope. ${ }^{18}$ And Swinburne's soured judgment late in life that he "never thought him [Arnold] worth serious consideration" as a literary critic and only a "cultured dunce" about French literature ("most seriously and sedately silly") 19 is not far from his warning readers in 1867 that in matters of French verse, Arnold, simply, is "not competent to speak." ${ }^{20}$ It is no wonder that Sydney Coulling finds Swinburne's phrasing about Arnold in this speech unusual, inconsistent, noteworthy. ${ }^{21}$

Without pretending to offer a final explanation of the curious tone in Swinburne's remarks, I would like to suggest that Swinburne may here be working satirically, in effect using irony to take advantage of the expectations of decorum implicit at such an august gathering and to entice his audience into an untenable acquiescence in what they hear. By accepting the proffered praise of Baudelaire's deep engagement with English literature (and the compliment to England that implies) and of Arnold's with French literature, the audience, in effect, reveals its literary ignorance-just as, in Swinburne's view, Arnold, by not coming to any proper appreciation of Baudelaire (or Hugo, for that matter!), had revealed his.

In short, I think it might be possible to see Swinburne's speech in the tradition of the burlesques and parodies so important to his work, especially in the $1860 \mathrm{~s}$. If

16/Munby, Man of Two Worlds: The Life and Diaries of Arthur J. Munby, 1828-1910, by Derek Hudson (n.p., 1972), pp. 220, 224. Munby offers evidence too of Swinburne's admiration of Baudelaire later in 1866, on December 2, when he heard Swinburne discourse of Poe, Whitman, and "Bourdelaire [sic], a certain ribald French poet, whom he declared to be " 15 million times' better than Tennyson" (p. 233).

17 / Swinburne commented of Baudelaire in 1862 that "to some English readers the name of M. Baudelaire may be known rather through his admirable translations, and the criticisms on American and English writers appended to these, and framing them in fit and sufficient commentary, than by his volume of poems" ("Charles Baudelaire," in Bonchurch ed., 13:418). Even taking into account Baudelaire's scattered comments on such English writers as Byron, such a desire as that to see Melmoth the Wanderer well translated, and, of course, his translation of De Quincey's Confessions of an English Opium Eater, it is difficult to see Baudelaire as having "devoted half his time to the translation and introduction of English writers among the French."

18/"As for Professor Arnold's Merope the clothes are well enough but where has the body gone? So I thought, and still think, the field was clear for me" (Letters, 1:115).

19/Ibid., 6:205.

20/Swinburne, “Matthew Arnold's New Poems," in Bonchurch ed., 15:104.

21/Sydney M. B. Coulling, "Swinburne and Arnold," Philological Quarterly 49 (1970): 218. 
that is so, the approach would seem to fit that which Patricia Clements explores in her most interesting book Baudelaire and the English Tradition. Although Clements does not comment on the curious misstatements Swinburne makes about Arnold and Baudelaire, she does brilliantly explore Swinburne's fascination with Baudelaire and establish his priority in the acceptance of Baudelaire as a modern poet. She draws special attention to the pattern of Swinburne's engagement with Baudelaire, showing not only the frequency and depth of his comments on Baudelaire and their utility to him but also how Swinburne "makes Baudelaire part of his fascination with dupery and disguise." Clements notes that Swinburne makes Baudelaire "serve his own opposition to critical and moral conventions." 22 I would suggest that he also makes him serve to undercut the conventions of after-dinner toasts.

Indeed, to read the report (in sixteen pages of fine print- "the proceedings did not terminate until a late hour," noted The Times ${ }^{23}$ ) of this extremely self-conscious literary evening with its earnest discussions of literature and of the connections, responsibilities, and duties of literature is to read a catalog of precisely the kinds of demands on literature that Swinburne was, by the autumn of the year, to find himself explicitly battling in Notes on Poems and Reviews. ${ }^{24}$ It is, in fact, just possible that the evening's pious declarations, one after the other, from speaker after speaker, helped to color such a remark as that Swinburne makes about academies of art and of literature in 1868: "Exclusion and suppression of certain things in the range of art are not really possible to any academy upon earth, be it pictorial or literary. It is natural for academies to try, when any rare or new good thing comes before them in either kind; witness much of academic history in England as in France." 25

Certain it is that the speakers during the evening enforced a consistent and mutually supporting vision of literature's responsibilities beyond itself and its own excellence. A man whom Swinburne came to be quite fond of, Frederick Leighton, concluded the evening by reminding his listeners of the links between art and literature and of the power of art "to arouse and stir up the passions of man-and what is better...to solace and to soothe (cheers)." Minutes before, an acquaintance of Swinburne's, Sir John Simeon, perhaps rather portentously, quoted the poem by Tennyson prefatory to "The Palace of Art": "Beauty, Good, and Knowledge, are three sisters / Doating upon each other; friends of man / That dwell together under the same roof, / And never can be sundered without tears." The dean of Canterbury had chimed in as well, noting the preeminent influence of English literature in "the real guidance and elevation of nations in civilization and

22/ Patricia Clements, Baudelaire and the English Tradition (Princeton, N.J., 1985), p. 21.

23/ The Times (May 3, 1866), p. 14b.

24/Swinburne's own response to the Report is interesting: "I want to shew you the report of my speech at the Literary Fund Dinner, which is very queer to read, seeing what rows I have got into since" (Letters 1:213). One reading of this comment is that Swinburne views the controversy about Poems and Ballads as especially ironic since his comments in May went unchastised. Another, of course, is that Swinburne is simply contrasting the warmth of his reception in May with the coolness of his reception in August. Whatever his reaction, more than three decades later, in 1899, Swinburne accepted an appointment to an honorary seat offered by the Council of the Royal Literary Fund (Letters, 6:138). He was duly added as an officer of the corporation at the annual general meeting on March 8, 1899, though he is not recorded as attending the 109th anniversary dinner on April 20, 1899 (The Times [March 9, 1899], 11d; [April 22, 1899], 3f).

25/Swinburne, Notes on the Royal Academy Exhibition, 1868 (1868; reprint, New York, 1976), p. 43. 
morals," a proposition echoed by Judge Manockjee Cursetjee, from India, as also by Viscount Milton, who emphasized that "there is a great responsibility on all literary men in dealing with international questions (hear, hear)."

Speaking from his perspective, the bishop of St. David's marked the close connection between the church and literature, saying that "literature is the weapon which she [the Anglican church] does most employ" in her defense. Sir Willoughby Jones remarked that "there is no doubt that the tone of English literature is eminently Church of England," and ventured to say that Shakespeare's plays "are as good Church of England books as any in the English language." Even a military man, General Vincent Eyre, drawing on his troops' long battles with tedium in India, reminded the audience that "the interests of literature and the army are in some measure reciprocal (cheers)."

The application of such admonitions was, moreover, carefully made by the speakers just preceding Swinburne. Venables reveals in his remarks some hesitation about the moral tone of Atalanta in Calydon and Chastelard and reminds Swinburne that "as, at present, the representative of the future in English poetry, he has a great responsibility upon him, and a noble task to accomplish." Venables looks forward to Swinburne's dealing with "many pleasanter subjects" than Mary Stuart. Similar moral concerns seem to underlie Charles Kingsley's agreement "with every word that Mr. Venables has said of" Swinburne. Kingsley rather pointedly celebrates the refinement of English literature from being "the coarse, fierce, and often vain thing" that it had been a hundred or two hundred years before.

Even Lord Houghton's remarks read rather coolly, though, of course, he speaks as one whose responsibilities in encouraging donations include due caution about their expenditure. Nevertheless, if one can detect a possible anticipation of intellectual fireworks in his comments about the coming together of literary men ("there are thoughts in England at this moment-there are minds in England at this moment, which, if they were brought into electrical communication might produceheaven knows what!"), one can also detect some remarks aimed, perhaps ironically, at Swinburne, "a young man who will continue that race and carry on the torch" of literature as Tennyson had "when the great poets of the last time went away": "Upon the mind of Man He gave, / It pleaseth God to ride; / And make each passion-crested wave / Part of his mighty tide." If Houghton regarded literature as "a great duty of mankind," he was also adamant that the literary occupation "must be regulated in the life of this country, like all other occupations, by the great laws of supply and demand (hear, hear)."

One would like to know a good deal more about the evening of May 2, 1866, and especially to know more about the intentions and anticipations not only of Swinburne but also of Lord Houghton, so famed for his experimental combinations of guests on social occasions. Until that information is forthcoming, we need to approach Swinburne's speech gingerly. It may not be what it appears to be.

College of William and Mary 